\title{
Determination of Metals in Brazilian Coconut Water Using an Inductively Coupled Plasma Optical Emission Spectrometer
}

\author{
Rafael A. de Sousa, Nivaldo Baccan and Solange Cadore* \\ Instituto de Química, Universidade Estadual de Campinas, CP 6154, 13084-971 Campinas - SP, Brazil
}

\begin{abstract}
A presença de espécies metálicas na água de coco, provenientes de diferentes estados brasileiros, foi investigada. A técnica de ICP OES foi utilizada para determinar $\mathrm{Ca}, \mathrm{Mg}, \mathrm{Mn}, \mathrm{Fe}, \mathrm{Zn}$ e $\mathrm{Cu}$, sem mineralização da matriz. Utilizando parâmetros instrumentais otimizados as determinações apresentaram RSD geralmente menor que $2 \%$ e boa exatidão. Os valores de LOD (mg L-1) foram: $\mathrm{Ca}$ 0,06, Mg 0,004, Mn 0,02, Fe 0,16, Zn 0,008 e Cu 0,006. As faixas de concentração $\left(\mathrm{mg} \mathrm{L}^{-1}\right)$ dos analitos nas amostras estudadas foram: Ca (107 - 237), Mg (50 - 88), Mn (1 - 5) e Zn (0,04 - 0,18) e, considerando-se os valores diários recomendados para a ingestão de minerais (VD), estima-se que a ingestão de $400 \mathrm{~mL}$ da bebida contribua com 7\% do VD para Ca e Mg e 58\% do VD para o Mn.
\end{abstract}

The metal content of coconut water was investigated in samples from different Brazilian states. $\mathrm{Ca}, \mathrm{Mg}, \mathrm{Mn}, \mathrm{Fe}, \mathrm{Zn}$ and $\mathrm{Cu}$ were determined without a mineralization step using the ICP OES technique. Employing optimized instrumental parameters, RSD usually lower than $2 \%$ and good accuracy were obtained. LOD values $\left(\mathrm{mg} \mathrm{L}^{-1}\right)$ were: $\mathrm{Ca} 0.06, \mathrm{Mg} \mathrm{0.004,} \mathrm{Mn} \mathrm{0.02,} \mathrm{Fe} \mathrm{0.16,} \mathrm{Zn} 0.008$ and $\mathrm{Cu} 0.006$. The concentration ranges $\left(\mathrm{mg} \mathrm{L}^{-1}\right)$ of the analytes in the samples studied were: $\mathrm{Ca}(107$ - 237), Mg (50 - 88), Mn (1 - 5) and Zn (0.04 - 0.18). Considering the Reference Daily Intakes for Minerals (RDI) it was estimated that the nutritional contribution from the ingestion of $400 \mathrm{~mL}$ of the beverage corresponds to approximately $7 \%$ of the RDI for $\mathrm{Ca}$ and $\mathrm{Mg}$ and $58 \%$ for $\mathrm{Mn}$.

Keywords: metals, natural coconut water, ICP OES

\section{Introduction}

The worldwide harvested area and annual production of coconut fruit reaches 10.5 million hectares and 47.8 million metric tons, respectively. ${ }^{1}$ The edible coconut products are mainly known in tropical regions ${ }^{2,3}$ and in Brazil coconut trees have been cultivated in order to employ the edible pulp of the mature coconut in the production of coconut flakes, milk, oil and also for coconut cakes. ${ }^{3}$

Coconut water is the liquid part of the coconut (Cocos nucifera) endosperm. It has been widely consumed in tropical countries ${ }^{3}$ as a refreshing beverage and is also considered to have some medicinal properties. It may be used as an oral or intravenous liquid for hydration for gastric and intestinal problems $\mathrm{s}^{3-8}$ and also as a solvent for urinary stones in the endoscopic procedure of MUT (Multiple Ureteral Tubation), since its enzymatic composition enhances stone dissolution. ${ }^{9}$ This wide application of coconut water and its pulp can be justified by their chemical

* e-mail: cadore@iqm.unicamp.br composition (sugars, proteins, lipids, phenols, citric acid and mineral salts). ${ }^{3-9}$

In Brazil the commercial demand for coconut water has been growing ${ }^{10,11}$ and due to this, fast and efficient analytical methods are necessary in order to evaluate the chemical composition of this product. However, considering the inorganic constituents of coconut water, there is no systematic study on the macro and microconstituents present in Brazilian coconut water. Jeganathan used FAAS for the determination of $\mathrm{Na}, \mathrm{K}, \mathrm{Ca}$ and $\mathrm{Mg}$ in the natural coconut water from Sri Lanka. ${ }^{7}$ Santoso et al. determined mineral elements $(\mathrm{Na}, \mathrm{K}, \mathrm{Ca}$, $\mathrm{Mg}, \mathrm{Mn}, \mathrm{Fe}, \mathrm{Zn}, \mathrm{Cu}, \mathrm{B}, \mathrm{Al}, \mathrm{P}$ and $\mathrm{S}$ ) in natural coconut water from Indonesia using ICP OES and a wet mineralization stage. ${ }^{8}$ In Brazil, Aleixo et al. determined Se in natural coconut water and coconut milk by graphite furnace atomic absorption spectrometry using the sample suspended in a mixture of tertiary amines soluble in water and employing $\mathrm{Pd}$ as chemical modifier. ${ }^{12}$ Recently an analytical method for the determination of macro and microconstituents in industrialized coconut water from Brazil was proposed, where the samples were analysed by 
Inductively Coupled Plasma Optical Emission Spectrometry (ICP OES) without a mineralization step. ${ }^{11}$ Although this matrix and natural coconut water may have similar characteristics, significative differences might be observed due to the industrialization processes. ${ }^{13}$ Therefore studies on analytical methods for the analysis of both natural and industrialized coconut water are still important.

ICP OES is and excellent technique for fast and accurate determinations of macro and microconstituents and has been applied in almost all the analytical chemistry areas. The wide employment of this technique for analysis of different kinds of matrices may be attributed to its multielemental capability and also because the analytical curves are generally linear over four to six orders of magnitude, which is necessary if the simultaneous aspect of the technique is to be fully utilized. ${ }^{14-16}$

In this work an analytical method for the determination of $\mathrm{Ca}, \mathrm{Mg}, \mathrm{Mn}, \mathrm{Fe}, \mathrm{Zn}$ and $\mathrm{Cu}$ in natural coconut water, using ICP OES, is described. Na and $\mathrm{K}$ were not included in this study since their content has already been reported as principal macroconstituents of this matrix ${ }^{4-8}$ (at about 0.10 and $6.08 \%$ of dry matter, respectively). ${ }^{8}$ The optimized experimental parameters were plasma power, nebulization flow rate and torch configuration. Because there is no coconut water standard reference materials the accuracy of the analytical method was evaluated using analyte addition and recovery experiments ${ }^{17}$ and also by analyzing a "Mixed Food Diet" as a reference material.

\section{Experimental}

\section{Instrumentation}

All the measurements were made with a Perkin-Elmer Inductively Coupled Optical Emission Spectrometer, Optima 3000DV, equipped with a peristaltic pump, a crossflow nebulizer coupled to a Ryton double pass spray chamber of the Scott type and a central torch tube injector with an internal diameter of $2.0 \mathrm{~mm}$. This instrument has a solid state segmented array charge coupled device (SCD) detector and operates sequentially in both radial and axial torch configurations. In the axial viewing mode, the cool plasma recombination area was striped off with a shear gas interface. The entire system is controlled with PE Winlab software. The conditions of operation of the spectrometer are presented in Table 1.

\section{Solutions and reagents}

Pure argon (99.996\%, White Martins, SP, Brazil) was used. Analytical solutions $\left(1000 \mathrm{mg} \mathrm{L}^{-1}\right.$ in $2 \% \mathrm{v} / \mathrm{v} \mathrm{HNO}_{3}$
Table 1. Instrument operating conditions for the determination of metals in natural coconut water

\begin{tabular}{ll}
\hline Sample flow rate $(\mathrm{mL} \mathrm{min}-1)$ & 1.0 \\
Radio frequency power $(\mathrm{kW})$ & 1.4 \\
Principal argon flow rate $(\mathrm{L} \mathrm{min}-1)$ & 15 \\
Auxiliary argon flow rate $\left(\mathrm{L} \mathrm{min}^{-1}\right)$ & 0.5 \\
Nebulization flow rate $(\mathrm{L} \mathrm{min}-1)$ & 0.6 \\
Read delay (s) & 30 \\
Auto integration (s, min. - máx.) & $1-5$ \\
Radial observation height (mm) & 15 \\
Replicates & 3 \\
Wavelengths (nm) & Ca II: 317.933 ; \\
& Mg II: $280.270 ;$ \\
& Fn II: $257.610 ;$ \\
& Fe II: $238.204 ;$ \\
& Cu I: 324.754 \\
Background correction & 2 points
\end{tabular}

(Carlo Erba Analyticals)) of each analyte were used. A Mixed Food Diet (High Purity Standards, CRM-MFD, USA, diluted in $2 \% \mathrm{v} / \mathrm{v} \mathrm{HNO}_{3}$ ) was used as reference material. All the glassware used was cleaned with dilute nitric acid $(10 \% \mathrm{v} / \mathrm{v})$ and then with deionized water (MilliQ system, $18.2 \mathrm{M} \Omega \mathrm{cm}$ ). The samples studied corresponded to eight coconuts from different Brazilian states and are identified according to their origin (São Paulo: SP; Paraíba: PB; Pará: PA; Bahia: BA and BA-A, Minas Gerais: MG; Rio Grande do Norte: RN and Rondônia: RD).

\section{Procedure}

The coconut water was taken from the fruit through an orifice opened with a stainless steel knife and then the samples were filtered through a G3 gooch filter (to guarantee the absence of solid particles, in order to avoid clogging the nebulizer). Solutions containing $20 \%(\mathrm{~m} / \mathrm{v})$ of the matrix were prepared in $2 \%(\mathrm{v} / \mathrm{v}) \mathrm{HNO}_{3}$.

The sample "SP" was spiked with $\mathrm{Mn}$ and Fe and analyzed at different nebulization flow rates (from 0.4 to $1.0 \mathrm{~L} \mathrm{~min}^{-1}$ ) and plasma powers (from 1.3 to $1.5 \mathrm{~kW}$ ), in an univariate form. The results were evaluated comparing the signal emission intensities obtained with these different conditions, considering the signal to noise ratios (SNR) and the signal to background ratios (SBR) for these elements. The signal to noise ratio was calculated by dividing the sample analyte emission intensity by the standard deviation of the blank $(n=10)$. The signal to background ratio is the analyte intensity divided by the blank signal. ${ }^{18}$

Employing optimized plasma power $(1.3 \mathrm{~kW})$ and nebulization flow rate $\left(0.6 \mathrm{~L} \mathrm{~min}^{-1}\right)$, analyte addition and recovery experiments for $\mathrm{Ca}, \mathrm{Mg}, \mathrm{Mn}, \mathrm{Fe}$ and $\mathrm{Zn}$ were carried out for samples "SP" and "PB" in order to evaluate 
matrix interferences and the accuracy of the proposed method. Under these conditions the torch configurations for each analyte were chosen according to the recoveries obtained for the species studied in both samples. The accuracy was also investigated by analysing a sample of Mixed Food Diet, under the optimized instrumental parameters that are presented in Table 1; the radial torch configuration was used for $\mathrm{Ca}, \mathrm{Mg}, \mathrm{Mn}$ and $\mathrm{Fe}$ and the axial configuration for $\mathrm{Zn}$ and $\mathrm{Cu}$.

Besides samples "SP" and "PB", six other samples were analysed with the previously optimized instrumental parameters. Regarding the results obtained a confidence interval $(\mathrm{t}=95 \%)$ was calculated for the elements studied.

\section{Results and Discussion}

\section{Instrumental parameters optimization}

In order to develop a method for the analysis of coconut water, plasma power and nebulization flow rate were optimized. Using $1.3 \mathrm{~kW}$ of plasma power the highest emission intensities were obtained when $0.6 \mathrm{~L} \mathrm{~min}^{-1}$ of nebulization flow rate was used, for both (axial and radial) torch configurations. Concerning the plasma power, it was observed that higher powers implied higher emission intensities. This means that excitation and ionization processes are improved by increasing the power. This behavior allows an increase in sensitivity for the elements studied and may minimize matrix effects. The employment of $0.6 \mathrm{~L} \mathrm{~min}^{-1}$ nebulization flow rate produced more intense emission signals when $1.5 \mathrm{~kW}$ of plasma power was used. This behavior was similar for all the elements studied when different nebulization flow rates and plasma power were employed.

These conditions are relevant mainly for the quantification of the elements that are present in low concentrations in coconut water. However, the use of higher plasma powers may increase the noise level and also the background signal affecting the determination of microconstituents, ${ }^{19}$ as Mn and Fe. On the other hand, Silva et $a l .{ }^{20}$ observed that the degradation of LOD values when the plasma was operated at high applied powers was not so large, compared to the values in low applied powers. Therefore, the SNR and the SBR for Mn and Fe were determined in order to evaluate the effect of plasma power, over an analytical range of 1.3 to $1.5 \mathrm{~kW}$. This analytical range was chosen concerning the default plasma power of the spectrometer $(1.3 \mathrm{~kW})$ and the recommendation of Boss et al. ${ }^{16}$ related to the use of $1.5 \mathrm{~kW}$ for the analysis of organic samples. Figure 1 presents the relationships between plasma power and SNR and SBR for the range of 1.3 to $1.5 \mathrm{~kW}$, obtained for the microconstituents $\mathrm{Mn}$ and Fe.
The graphics in Figure 1 show that the relation between SNR and plasma power was similar for Mn and Fe using the radial torch configuration. At $1.4 \mathrm{~kW}$ the noise values were smaller for Mn and Fe. Considering the background values, it can be noted that the smallest one occurs with $1.4 \mathrm{~kW}$ in the axial torch configuration for both analytes, while at the 1.4 and $1.5 \mathrm{~kW}$ plasma power levels the backgrounds were smaller for Fe using the radial torch configuration. For Mn SBR values were not obtained in this torch configuration, because blank solution did not produce emission signals. Then, $1.4 \mathrm{~kW}$ plasma power was chosen for all the determinations in this study.

Using these conditions the recoveries of macro $(\mathrm{Ca}$ and $\mathrm{Mg}$ ) and microconstituents ( $\mathrm{Mn}, \mathrm{Fe}, \mathrm{Zn}$ and $\mathrm{Cu}$ ) were between 90 and $110 \%$ as can be observed in Table 2. It means that there is not significant matrix interference ${ }^{17}$ when operating the plasma under the optimized conditions and the analysis can be carried out without a mineralization step of the sample. In addition, low matrix interference could also be verified comparing the slopes obtained for the analytical and analyte addition curves that showed similar values. Thus, optimized plasma power, nebulizer flow rate and torch configuration lead to determinations with good accuracy and satisfactory precision, since the RSD values were usually lower $2 \%$.

\section{Figures of merit}

The limits of detection (LOD) and the limits of quantification (LOQ) were calculated as suggested by

Table 2. Analyte concentrations and RSD for samples "SP" and "PB" and their recoveries in analyte addition and recovery experiments

\begin{tabular}{|c|c|c|c|}
\hline Element & $\begin{array}{l}\text { Concentration } \\
\left(\mathrm{mg} \mathrm{L}^{-1}\right)\end{array}$ & $\begin{array}{l}\text { Added mass } \\
(\mathrm{mg})\end{array}$ & $\begin{array}{l}\text { Recovery } \\
(\%)\end{array}$ \\
\hline $\mathrm{Ca}$ & $\begin{array}{l}\text { SP: } 204 \pm 0.1 \\
\text { PB: } 195 \pm 0.1\end{array}$ & $\begin{array}{l}0.16 \\
\text { SP: } 94 \pm 0.4 \\
\text { PB: } 94 \pm 0.2\end{array}$ & $\begin{array}{l}0.48 \\
\text { SP: } 103 \pm 0.5 \\
\text { PB: } 93 \pm 0.1\end{array}$ \\
\hline $\mathrm{Mg}$ & $\begin{array}{l}\text { SP: } 43 \pm 0.1 \\
\text { PB: } 71 \pm 0.04\end{array}$ & $\begin{array}{l}0.1 \\
\text { SP: } 96 \pm 0.7 \\
\text { PB: } 96 \pm 0.2\end{array}$ & $\begin{array}{l}0.3 \\
\text { SP: } 103 \pm 0.5 \\
\text { PB: } 96 \pm 0.2\end{array}$ \\
\hline $\mathrm{Mn}$ & $\begin{array}{l}\text { SP: } 4.5 \pm 0.2 \\
\text { PB: } 2.3 \pm 1.9\end{array}$ & $\begin{array}{l}0.01 \\
\text { SP: } 96 \pm 0.5 \\
\text { PB: } 98 \pm 0.1\end{array}$ & $\begin{array}{l}0.03 \\
\text { SP: } 101 \pm 1.6 \\
\text { PB: } 95 \pm 0.7\end{array}$ \\
\hline $\mathrm{Fe}$ & $\begin{array}{l}\text { SP: < LOD } \\
\text { PB: < LOD }\end{array}$ & $\begin{array}{l}0.01 \\
\text { SP: } 98.2 \pm 1.4 \\
\text { PB: } 93 \pm 2.5\end{array}$ & $\begin{array}{l}0.03 \\
\text { SP: } 97 \pm 1.2 \\
\text { PB: } 95 \pm 0.2\end{array}$ \\
\hline $\mathrm{Zn}$ & PB: $0.2 \pm 1.1$ & $\begin{array}{l}0.01 \\
\text { PB: } 100 \pm 1.8\end{array}$ & $\begin{array}{l}0.03 \\
\text { PB: } 99 \pm 0.9\end{array}$ \\
\hline $\mathrm{Cu}$ & PB: $<$ LOD & $\begin{array}{l}0.01 \\
\text { PB: } 97 \pm 0.2\end{array}$ & $\begin{array}{l}0.03 \\
\text { PB: } 99 \pm 0.9\end{array}$ \\
\hline
\end{tabular}



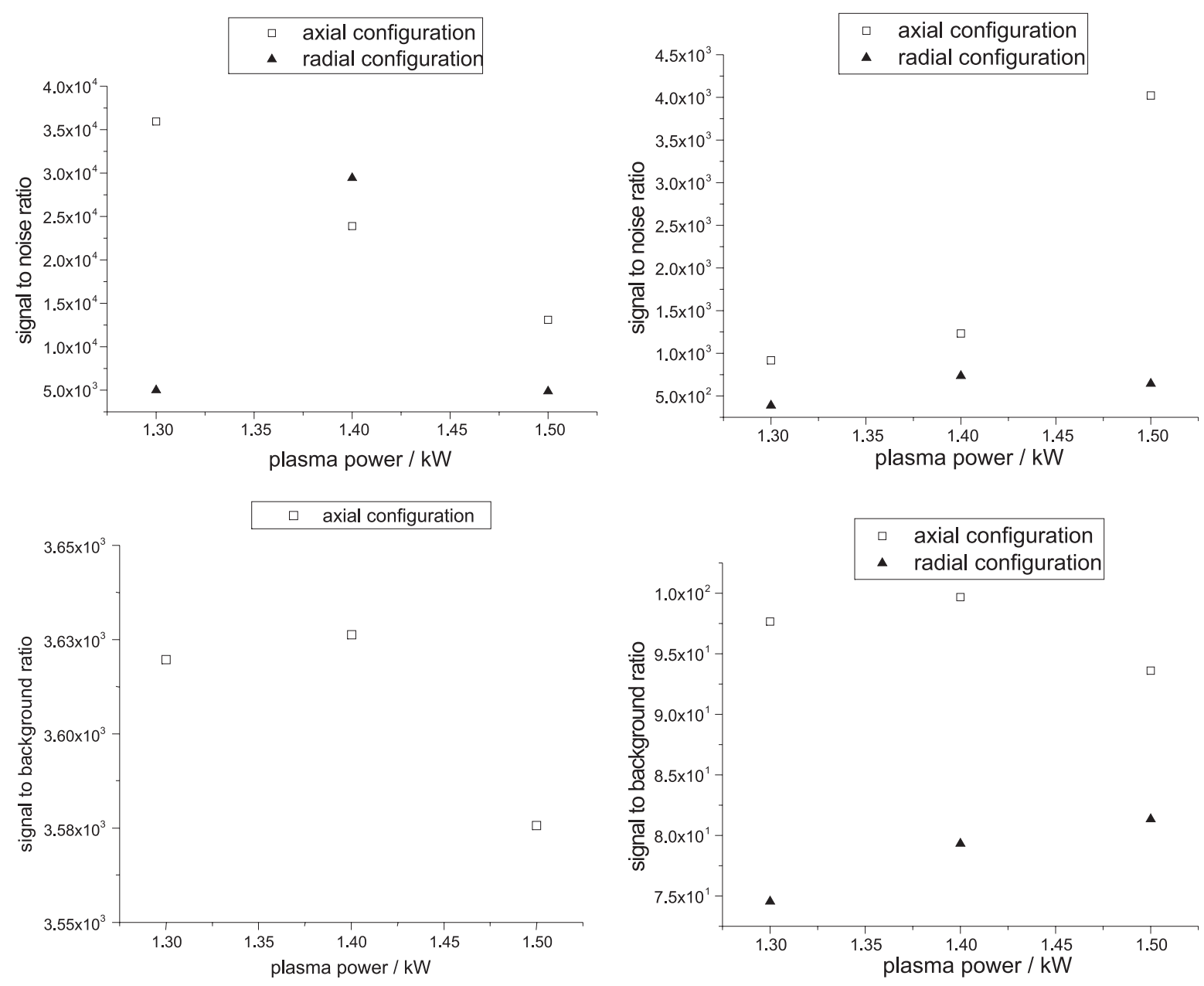

Figure 1. Relation between SNR and plasma power, and between SBR and plasma power for the microconstituents Mn e Fe.

Montaser: ${ }^{21} \mathrm{LOD}=(3 \mathrm{RSD} \mathrm{BEC}) / 100$ and $\mathrm{LOQ}=5 \mathrm{LOD}$, where $R S D$ is the relative standard deviation $(\mathrm{n}=10)$ and $B E C$ is the background equivalent concentration, determined experimentally. The LOD values obtained are presented in Table 3.

Due to the lack of a certified reference material for coconut water the accuracy of the method was evaluated by using the "Mixed Food Diet" reference material, considering the similarity of composition between this sample and coconut water. The results obtained with the proposed procedure are also shown in Table 3, with good agreement concerning the declared values.

Table 3. Limits of detection, LOD (mg L $\left.\mathrm{L}^{-1}\right)$, and concentrations (mg L $\left.\mathrm{L}^{-1}\right)$ obtained for the Mixed Food Diet material

\begin{tabular}{llcc}
\hline Element & LOD & Observed Value & Declared Value \\
\hline $\mathrm{Ca}$ & 0.06 & $38.6 \pm 0.4$ & 40 \\
$\mathrm{Mg}$ & 0.004 & $15.7 \pm 0.1$ & 12 \\
$\mathrm{Mn}$ & 0.019 & $0.20 \pm 0.01$ & 0.2 \\
$\mathrm{Fe}$ & 0.16 & $0.82 \pm 0.01$ & 0.8 \\
$\mathrm{Zn}$ & 0.008 & $0.27 \pm 0.01$ & 0.3 \\
$\mathrm{Cu}$ & 0.006 & $0.06 \pm 0.01$ & 0.06 \\
\hline
\end{tabular}

Analysis of samples from different Brazilian states

The concentrations of the elements studied in different samples are shown in Table 4, where the values have been corrected for sample dilution.

Comparing the results between the different samples it was verified that $\mathrm{Ca}$ and $\mathrm{Mg}$ are macroconstituents while $\mathrm{Mn}$ and $\mathrm{Zn}$ are microconstituents in Brazilian coconut water. In Table 4 some concentrations values are below the LOQ but they may be considered estimated values for the concentrations of these elements because they are higher than 5 times the LOD values. ${ }^{16}$

The macro and microconstituents determined in the samples were also reported in the samples from other countries, ${ }^{7.8}$ however their concentrations are at different levels while the elements $\mathrm{Fe}$ and $\mathrm{Cu}$ were not detected in Brazilian samples.

In order to establish a range for the concentration $(\mathrm{mg}$ $\left.\mathrm{L}^{-1}\right)$ of the elements studied, a confidence interval $(\mathrm{t}=95 \%)$ was calculated for each element: $\mathrm{Ca}$ (107 - 237), $\mathrm{Mg}$ (50 $88), \mathrm{Mn}(1-5)$ and $\mathrm{Zn}(0.04-0.18)$. Considering the mean 
Table 4. Concentrations $\left(\mathrm{mg} \mathrm{L}^{-1}\right)$ and $\mathrm{RSD}$ for $\mathrm{Ca}, \mathrm{Mg}, \mathrm{Mn}, \mathrm{Fe}, \mathrm{Zn}$ and $\mathrm{Cu}$ determined in different samples of natural coconut water

\begin{tabular}{lllllll}
\hline Metal & PA & BA & BA - A & MG & RN & RD \\
\hline $\mathrm{Ca}$ & $149(2)$ & $167(0.6)$ & $146(4)$ & $331(2.5)$ & $65(1.6)$ & $122(3)$ \\
$\mathrm{Mg}$ & $57(2)$ & $101(0.3)$ & $104(4)$ & $60(1.8)$ & $73(2.4)$ & $49(3)$ \\
$\mathrm{Mn}$ & $1.7(2.2)$ & $7.9(0.1)$ & $3.6(3.5)$ & $2.2(0.6)$ & $0.2(0.1)$ & $1.1(2.3)$ \\
$\mathrm{Fe}$ & $<$ LOD & $<$ LOD & $<$ LOD & $0.18(4)^{\mathrm{a}}$ & $<$ LOD & $<$ LOD \\
$\mathrm{Zn}$ & $0.25(1.4)$ & $<$ LOD & $0.13(16)^{a}$ & $0.22(6.4)$ & $<$ LOD & $0.12(18)^{\mathrm{a}}$ \\
$\mathrm{Cu}$ & $<$ LOD & $<$ LOD & $<$ LOD & $0.04(9.4)^{a}$ & $<$ LOD & $<$ LOD \\
\hline
\end{tabular}

${ }^{a}$ Estimated values.

values of these ranges and the "Reference Daily Intakes for Minerals" (IDR), ${ }^{22}$ it can be estimated that the ingestion of $400 \mathrm{~mL}$ of natural coconut water contributes approximately $7 \%$ of the $\mathrm{Ca}$ and $\mathrm{Mg}$ IDR, $58 \%$ of the $\mathrm{Mn}$ IDR and $0.3 \%$ of the Zn IDR.

\section{Conclusions}

The proposed method allows the determination of $\mathrm{Ca}$, $\mathrm{Mg}, \mathrm{Mn}, \mathrm{Fe}, \mathrm{Zn}$ and $\mathrm{Cu}$ in natural coconut water without a mineralization treatment using a radially configured ICP OES for $\mathrm{Ca}, \mathrm{Mg}, \mathrm{Mn}$ and $\mathrm{Fe}$ and an axially one for $\mathrm{Zn}$ and $\mathrm{Cu}$. Simultaneous, multielemental, fast, precise and accurate determinations are the main characteristics of the proposed analytical method. The analysis of different samples of natural coconut water allow to establish a statistical interval for the concentration of the macro and microconstituents in Brazilian samples and the results may contribute to the determination of the chemical composition of the natural coconut water.

\section{Acknowledgements}

The authors gratefully acknowledge Dr. Carol H. Collins for assistance with English in this manuscript and the Fundação de Amparo à Pesquisa do Estado de São Paulo (FAPESP) and the Fundação de Apoio ao Ensino e Pesquisa (FAEP) for financial support of this work.

\section{References}

1. FAO - Food and Agricultural Organization of the United Nations - Database on http://apps.fao.org/, accessed in July 2003.

2. Ullmann's Encyclopedia of Industrial Chemistry; $5^{\text {th }}$ ed., $\mathrm{VCH}$ Publishers: Weinheim, 1987, vol. A10.

3. Campos, C. F.; Souza, P. E. A.; Coelho, J. V.; Glória, M. B. A.; J. Food Process. Preserv. 1996, 20, 487.

4. Acharya, V. N.; Grepta, K. C.; Golwala, A. F.; Store, S. D.; Sheth, U. K.; Ind. J. Med. Res 1965, 53, 1069.

5. Kubersky, T.; Roberts, A.; Linehan, B.; Bryden, R. N.; Teburare, M.; New Zeal. Med. J. 1979, 90, 98.
6. Cooper, E. S.; Lancet 1986, 2, 281.

7. Jeganathan, M.; Commun. Soil Sci. Plant Anal. 1992, 23, 2667.

8. Santoso, U.; Kubo, K.; Ota, T.; Tadokoro, T.; Maekawa, A.; Food Chem. 1996, 57, 299.

9. Macalalag, E. V.; Int. Surg. 1987, 72.

10. Brito, N. M.; Navickiene, S.; Polese, L.; Jardim, E. F. G.; Abakerli, R. B; Ribeiro, M. L.; J. Chromatrogr. A 2002, 957, 201.

11. De Sousa, R. A.; Silva, J. C. J.; Baccan, N.; Cadore, S.; J. Food Comp. Anal. 2005, 18, 399.

12. Aleixo, P. C.; Nóbrega, J. A.; Santos Júnior, D.; Muller, R. C. S.; Quim. Nova 2000, 23, 310.

13. Reilly, C., ed.; Metal Contamination of Food, Elsevier: New York, 1991

14. Thompson, M.; Walsh, J. N.; Handbook of Inductively Coupled Plasma Spectrometry, $2^{\text {nd }}$ ed., Blackie: Glasgow, 1989.

15. Skoog, D. A.; Holler. F. J.; Nieman, T. A.; Principles of Instrumental Analysis, $5^{\text {th }}$ ed., Saunders College Publishing: Philadelphia, 1998.

16. Boss, C. B.; Fredeen, K. J.; Concepts, Instrumentation and Techniques in Inductively Coupled Plasma Optical Emission Spectrometry, $2^{\text {nd }}$ ed, Perkin-Elmer Corp.: Norwalk, 1999.

17. Crosby, N. T.; Day, J. A.; Holcombe, D. G.;Treble, R. D.; Prichard, F. E.; Quality in Analytical Chemistry Laboratory, John Wiley: Chichester, 1995

18. Thomsen, V.; Roberts, G.; Burgess, K.; Spectroscopy 2000, 15,33 .

19. Brenner, I. B.; Zander, A.; Cole, M.; Wiseman, A.; J. Anal. At. Spectrom. 1997, 12, 897

20. Silva, J. C. J.; Baccan, N.; Nóbrega, J. A.; J. Braz. Chem. Soc., 2003, 14, 310

21. Montaser, A.; Golightly, D. W.; Inductively Coupled Plasmas in Analytical Atomic Spectrometry, $2^{\text {nd }}$ ed, VCH: New York, 1992.

22. Altman, T. A.; FDA and USDA Nutrition Labeling Guide Decision Diagrams, Ckecklists and Regulations; Technomic Publishing Co.: Pennsylvania, 1998.

Received: April 7, 2004 Published on the web: March 4, 2005

FAPESP helped in meeting the publication costs of this article. 